\title{
Adoption of parasitic Maculinea alcon caterpillars (Lepidoptera: Lycaenidae) by three Myrmica ant species
}

\author{
THOMAS DAMM ALS*, DAVID R. NASH*† \& JACOBUS J. BOOMSMA*† \\ *Department of Ecology and Genetics, University of Aarhus \\ $\nmid$ Zoological Institute, Department of Population Ecology, University of Copenhagen, Denmark \\ (Received 10 July 2000; initial acceptance 14 October 2000; \\ final acceptance 31 January 2001; MS. number: 6631R)
}

\begin{abstract}
Maculinea butterflies are parasites of Myrmica ant nests. The Alcon blue, Maculinea alcon, is unusual in that it parasitizes the nests of several Myrmica species, using M. rubra, M. ruginodis and M. scabrinodis as hosts in different parts of Europe. In Denmark it uses M. rubra and M. ruginodis, but never M. scabrinodis. Some populations use one of these species exclusively, despite the presence of the alternative host, while others use both hosts simultaneously. To examine the basis of this specificity, and local coadaptation between host and parasite, we offered freshly emerged caterpillars of M. alcon from three populations differing in their host use to laboratory nests of all three recorded host ant species collected from each of the M. alcon populations. We measured the attractiveness of the caterpillars to their host ants as the time taken for them to be adopted by each ant colony. Caterpillars from all populations took longer to be adopted to M. scabrinodis nests than to nests of the other two ant species. Adoption times to M. rubra and M. ruginodis colonies differed: caterpillars from each of the two populations that used a single host species were adopted most quickly by that species when local ant colonies were used. When ant colonies collected from the other two sites were used, this pattern broke down, and there was either no difference in adoption time, or M. rubra adopted caterpillars more quickly. Adoption of caterpillars from the population that used both M.rubra and M.ruginodis as hosts took an order of magnitude longer than caterpillars from populations using a single host species.
\end{abstract}

() 2001 The Association for the Study of Animal Behaviour

Associations with ants are extremely widespread and diverse among the butterfly family Lycaenidae (Fiedler 1991). These relationships normally occur during the larval stage and are mediated by chemical, nutritional and mechanical communication (Fiedler et al. 1996). Most lycaenid-ant relationships are believed to be mutualistic, in which the caterpillars provide the attendant ants with nutrition in return for protection. These mutualistic interactions are mostly facultative and relatively unspecific (Pierce 1987; Fiedler 1991). A few obligate mutualistic interactions are, however, extremely intimate, specific and crucial for larval survival (Pierce 1987; Fiedler 1991, 1998). Very high levels of specificity also occur in the few parasitic lycaenids, including the Palaearctic genus Maculinea van Eecke which parasitizes colonies of ants of the genus Myrmica Latreille.

All five European species of Maculinea are initially phytophagous, with females ovipositing on the inflorescences of specific perennial host plants, which flower only in mid summer (Thomas et al. 1998a). The young Correspondence: T. D. Als, Department of Ecology and Genetics, University of Aarhus, Building 540, Ny Munkegade, DK-8000 Aarhus C, Denmark (email: thomas.als@biology.au.dk).

0003-3472/01/070099+08 \$35.00/0 caterpillars develop quickly through the first three instars, and on moulting to the fourth (and final) larval instar, they leave their food plant in late July or August. They then apparently mimic the larvae of Myrmica ants to ensure that they are found and adopted by foraging Myrmica workers (Akino et al. 1999). The caterpillars live inside the ant nest for 10-11 months, gaining some $98 \%$ of their final biomass either as predators eating the ant's brood (Thomas \& Wardlaw 1992) or in a cuckoo-like manner, being actively fed by the ants (Elmes et al. 1991a, b). The caterpillars pupate here, and normally eclose as adults the summer after they were adopted, although some caterpillars may take 2 years to develop (Thomas et al. 1998b; Schönrogge et al. 2000; T. D. Als \& D. R. Nash, unpublished data).

On many Maculinea sites, up to eight species of Myrmica forage beneath the Maculinea food plants, and are apparently equally good at finding the caterpillars and carrying them into their nests (Elmes et al. 1991b; Thomas \& Elmes 1998), although Liebig (1989) mentioned differential acceptance of Maculinea alcon Denis \& Shiffermüller caterpillars by two Myrmica species. Work by Thomas et al. (1989) suggested, however, that each Maculinea 
species, once adopted, can be successfully reared to adulthood by only a single species of Myrmica, although secondary hosts sometimes rear a small fraction of the population (Figurny \& Woyciechowski 1998; Thomas \& Elmes 1998). Maculinea alcon is an exception, successfully using three Myrmica species as hosts in different parts of its western European distribution. It uses M. scabrinodis Nylander as a host in southern Europe, M. ruginodis Nylander in central Europe and M. rubra (L.) in the north (Elmes et al. 1994). Elmes et al. (1994) therefore suggested that M. alcon might consist of three subspecies or cryptic species each using a different species of Myrmica as host. Maculinea alcon is distributed from southern Sweden and Denmark to the northern part of Spain (Wynhoff 1998). The distributions of M. alcon and its host ants in the eastern part of its range are less well known (Wynhoff 1998). The marsh gentian, Gentiana pneumonanthe L., is the host plant of the first three instars of M. alcon throughout its western European distribution (Tolman \& Lewington 1997).

Population-specific differences in allozyme genotypes of M.alcon in Denmark (Gadeberg \& Boomsma 1997) suggest that genetically differentiated forms may also occur in this part of the species' distribution, possibly in relation to the use of different host ants. This pattern in genetic variation is at least partially consistent with variation in wing pattern (Kaaber 1964). There are also indications that two gene pools coexist in certain populations, possibly associated with the use of different host ants, since populations are significantly less heterozygous than expected (Gadeberg \& Boomsma 1997). Populations of M.nausithous Bergsträsser and M. teleius Bergsträsser, which both use a single host ant species, but which otherwise are as fragmented as M.alcon, show no such lack of heterozygosity (Figurny-Puchalska et al. 2000).

A survey carried out between 1997 and 1999 confirmed that both M. rubra and M. ruginodis are used as host ants in Denmark, and that specificity is not complete for many of the Danish M. alcon populations (T. D. Als \& D. R. Nash, unpublished data). Of five populations investigated in detail, one used exclusively M. rubra as a host and another exclusively $M$. ruginodis, but the remaining three used both ant species within the same site. No populations parasitized M. scabrinodis (T. D. Als \& D. R. Nash, unpublished data). There are clear differences between M. ruginodis and M.rubra in terms of colony size, kin structure (Elmes 1991; Elmes \& Keller 1993; Seppä 1994, 1996) and glandular chemistry (Bagnères \& Morgan 1991; Akino et al. 1999) which might be expected to select for host specificity. The apparent simultaneous use of two host ant species by some M. alcon populations but not by others therefore raises interesting questions about the evolution and coadaptation of parasites and hosts. The stable use of two alternative host species would imply that parasite fitness is to some extent independent of host species. The exclusive use of some host ant species in some sites (despite the presence of the alternative host) suggests that this is not, however, always the case. Selection pressure for host specificity and parasite-host coevolution thus seems to vary geographically.
To investigate the basis of the geographical variation in host use of M. alcon in Denmark, we studied the coadaptation of hosts and parasites under controlled conditions. A critical stage in the life cycle of M. alcon is that when the caterpillars have emerged from the host plant and before they enter the host ant nest. This is the only period when they are not largely protected from potential predators and parasites by being surrounded either by plant tissue or an aggressive ant colony. In addition, fourthinstar caterpillars can feed only inside a Myrmica nest, so that there is a real danger of starvation if they are not adopted quickly. Hence caterpillars are expected to show adaptations to ensure speedy discovery and adoption by appropriate host ants. We therefore used adoption time as a measure of the degree of attractiveness of M. alcon to potential host ant species from both local and distant populations.

\section{METHODS}

We collected ant colonies and caterpillars at three sites in Denmark from mid-July to mid-August 1998. Each of the three sites differed in the ant species M. alcon used as a host. At site 1 (Læsø Rønnerne), on the island of Læs $\varnothing$ northeast of Jutland $\left(57^{\circ} 14^{\prime} \mathrm{N}, 11^{\circ} 1^{\prime} \mathrm{E}\right)$, the butterfly used both $M$. rubra and M. ruginodis as host species. We refer to this site as BOTH. At site 2 (Gyttegård) in the midwest of Jutland $\left(55^{\circ} 43^{\prime} \mathrm{N}, 9^{\circ} 3^{\prime} \mathrm{E}\right)$ M. ruginodis was the only ant species used as a host. We refer to this site as RUG. At site 3 (Vejers: $55^{\circ} 37^{\prime} \mathrm{N}, 8^{\circ} 12^{\prime} \mathrm{E}$ ) in the westernmost part of Jutland the butterflies used M. rubra as a host. We refer to this site as RUB.

\section{Collection of M. alcon Caterpillars}

Since the eggs of M. alcon are white and are laid on the outside of the flower buds of G. pneumonanthe they are very conspicuous. We collected caterpillars from the field by gathering gentian stalks with visible eggs. A stalk was collected only if it had more than five eggs present and if there was at least one other stalk with a greater number of eggs within $50 \mathrm{~cm}$. We adopted this collection strategy to minimize the impact of our collections on the M. alcon populations.

Unlike three of the other European Maculinea species, M. alcon is not listed in the appendices to the Bern Convention or Habitats Directive. Munguira \& Martin (1999) concluded that M. alcon should be classified as vulnerable on a European scale, and also vulnerable in Denmark (IUCN classifications). Within Denmark M. alcon has declined over the last century, primarily because of changes in land use, with some $69 \%$ of previously recorded populations having been recorded in surveys after 1990 (Gadeberg \& Boomsma 1997).

The populations of M. alcon in Denmark vary considerably in size and vulnerability to changes in land use. The three populations in the current study were chosen because they are among the largest populations (R. Gadeberg, unpublished data), and they are all in areas where land use is, and has been over the last few decades, 
such as to encourage populations of M. alcon and its host ants. The sites at Læsø Rønnerne and Gyttegård are protected wet heathlands maintained by light cattle grazing, while that at Vejers is on a military training range protected from public access and agricultural development. Permission to conduct the field work was obtained from the Danish Forest and Nature Agency and local military authorities, respectively.

While life table analysis of the stages and causes of mortality has not been carried out, in the course of our fieldwork in Denmark we have collected data on the density of eggs of M. alcon on gentian plants, and on the number of M. alcon caterpillars in Myrmica ant nests. A preliminary analysis of the data suggests that the mortality between the egg stage and adoption into an ant nest is at least $85 \%$ and probably considerably higher. It should therefore be at this stage that the M. alcon populations can most withstand harvesting, which is why we collected M. alcon as eggs from the field.

Once adopted by the ant colony in our study, the caterpillars stayed in the colony taking part in a survival experiment that continued until pupation and emergence of adult butterflies. Survival to adulthood was low (some 4\%, comparable with field estimates based on female clutch size). All emerging adults, together with the remains of caterpillars and pupae that died during the study, were preserved for genetic analysis. We killed the adults by firmly squeezing the thorax.

In the laboratory, four or five collected gentian stalks were placed in a disposable plastic cup with water and fertilizer and these remained fresh on a laboratory table for 2-3 weeks. We placed a funnel around the stalks just beneath the lowest flower bud, to prevent caterpillars from drowning when they fell from the plant (Gadeberg \& Boomsma 1997). The plants and the water cups were placed in large plastic boxes $(35 \times 22 \mathrm{~cm}$ and $18 \mathrm{~cm}$ high) coated with Fluon (ICI Plc., Runcorn, U.K.) to prevent the caterpillars from escaping. We checked the plants at least hourly from 0600 to 0300 hours each day. Any caterpillars that had emerged from the gentian plants and let themselves down on to the funnel or into the plastic box were immediately weighed to the nearest $0.01 \mathrm{mg}$ with a Sartorius balance. A small number of caterpillars emerged prematurely, before reaching their fourth instar, so we determined the instar of each caterpillar by examining its external morphology under a binocular microscope. Fourth-instar larvae (easily distinguished by their dorsal nectary organ, a structure absent from earlier instars: see Kitching \& Luke 1985) were collected and used for the adoption experiment. In all, 866 out of 996 emerging caterpillars (87\%) were fourth instars.

\section{Collection of Myrmica Ant Nests}

We searched each of the three sites for ant nests of the genus Myrmica, species being identified with keys by Kutter (1977), Collingwood (1979) and Wardlaw et al. (1998). Whole nests with queens of the species M. rubra, M. ruginodis and M. scabrinodis were excavated and brought to the laboratory. We collected 54 colonies in the field (18 M. rubra nests, 24 M.ruginodis and 12
M. scabrinodis) and divided them into experimental subcolonies, each with a single queen, as follows. Twenty field colonies had at least three queens and were divided into three subcolonies, each of which was to be presented with M. alcon caterpillars from one of the three sites. Seven colonies had two queens and were divided into two subcolonies, again to be presented with caterpillars from different sites. Twenty-six colonies had only one queen and produced a single subcolony. One colony with more than six queens was divided into six subcolonies, the second trio being used to replace another colony that died during transport. This gave a total of 106 experimental subcolonies (see below). Each of the subcolonies was provided with 250 workers and an equal portion of the brood from its mother colony.

We constructed nests for each subcolony from a transparent plastic foraging arena $(78 \times 56 \mathrm{~mm}$ and $48 \mathrm{~mm}$ high) connected by a silicon tube of $8 \times 65 \mathrm{~mm}$ to an opaque grey nestbox of the same dimensions with an opaque lid. Half of the floor area of the nestbox was covered with plaster, which was moistened with distilled water to maintain a high humidity. The colonies were fed in the foraging arena with frozen adult Drosophila and artificial diet (Bhatkar \& Whitcomb 1970). Water was provided in the nest area in small glass tubes, plugged with cotton wool. During the experiment we changed water and food weekly in each of the colonies.

\section{Adoption Experiment}

For the ant species M. rubra and M.ruginodis, we set up experimental nests in a three-way full factorial design, with caterpillar source site, ant source site and ant species as the three factors. Within each treatment there were five replicate colonies (except for M. ruginodis subcolonies from site BOTH receiving caterpillars from site $\mathrm{BOTH}$, where an additional replicate was accidentally included). For M. scabrinodis subcolonies, a full factorial design was not used, with caterpillars from each site being presented only to ant colonies collected from the same site. This was done partly for logistical reasons, since it proved impossible to collect sufficient M. scabrinodis colonies with queens in the field for a full factorial design, but mostly because M. scabrinodis is not known to be a host of M. alcon in Denmark, so that local adaptation is not expected. Figure 1 in the Results shows the sample sizes.

Pilot experiments carried out in 1997 suggested that the adoption of a single caterpillar of M. alcon by a Myrmica colony may facilitate adoption of subsequent caterpillars. Since female M. alcon lay eggs in clusters, the caterpillars of which emerge from their host plants at about the same time (often using the same emergence hole; personal observation), we decided to offer four caterpillars to each subcolony simultaneously.

We introduced caterpillars to the experimental subcolonies as quickly as possible after they had left the food plant subject to this constraint. Caterpillars that could not be introduced to an ant colony within ca. $1 \mathrm{~h}$ of emergence from the host plant because of a shortage of fellow caterpillars were not used. We standardized the number of caterpillars per subcolony to four, for an 

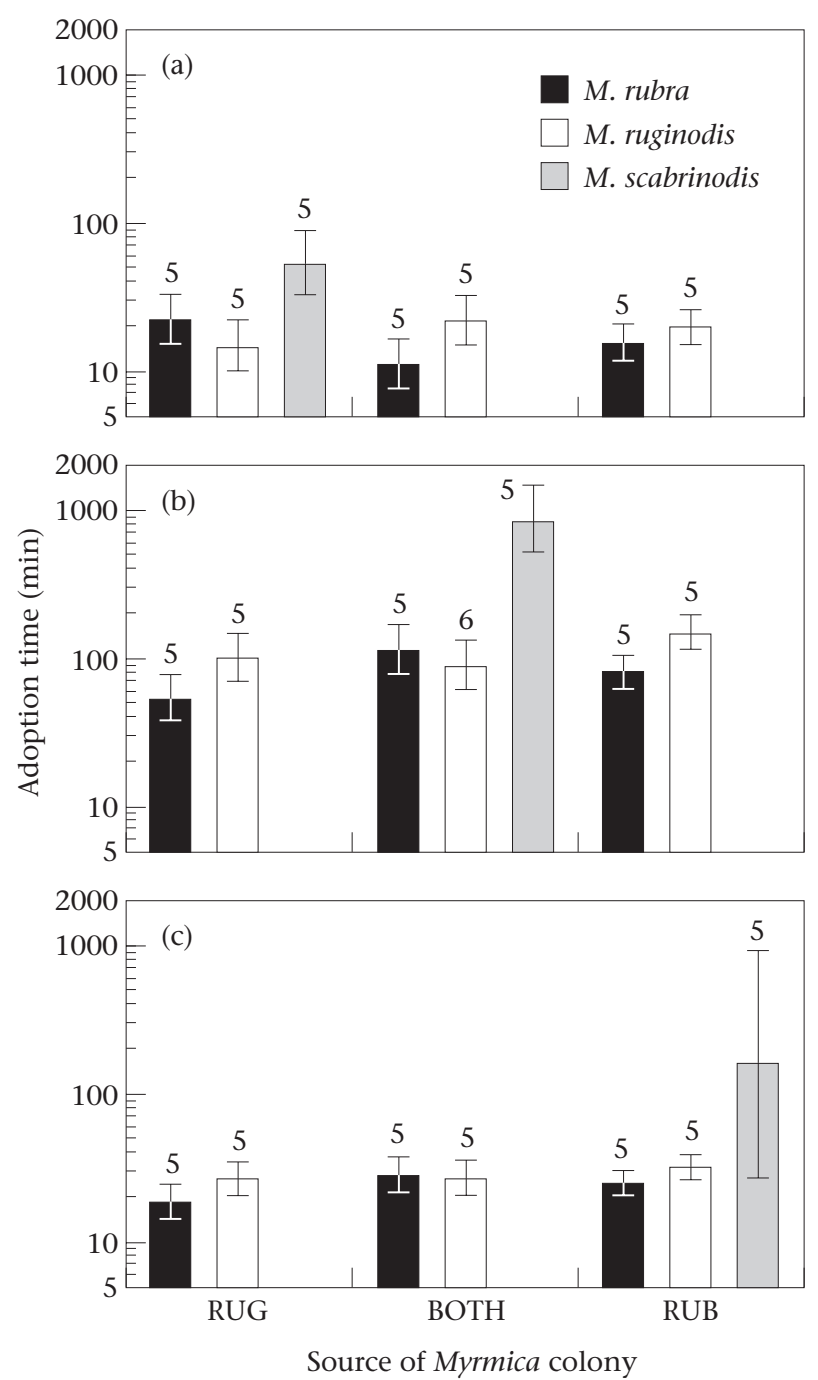

Figure 1. Mean adoption times of Maculinea alcon caterpillars by Myrmica ants and $95 \%$ confidence intervals around the mean for all combinations of caterpillar source site (RUG, RUB and BOTH), ant source site and ant species ( $M$. rubra, $M$. ruginodis, $M$. scabrinodis). At site RUG, M. alcon used M. ruginodis as the host species, at site RUB M. rubra, and at site BOTH both species were used. Caterpillars from (a) site RUG, (b) site BOTH and (c) site RUB were presented to Myrmica from each site. Means and 95\% confidence intervals are estimated from survival analysis of adoption times with log-normal error distribution. Values above bars indicate sample sizes for each treatment. Caterpillars presented to M. scabrinodis colonies were presented only to colonies from the site where they were collected.

additional study of their development (unpublished data).

We placed the four caterpillars at the end of the foraging arena furthest from the nest chamber entrance in each nest. We measured adoption time for each of the four caterpillars as the time (min) from placing the caterpillar in the foraging arena until it was brought through the connecting tube into the nest chamber by a worker ant. We observed nests continuously after introduction of the caterpillars, except from 0300 to 0600 hours, for practical reasons. Any caterpillars that were adopted during this time were assigned adoption times corresponding to adoption at 0430 hours. The last experiment of the day was always started before 2400 hours, and all caterpillars that were adopted by the colony unobserved between 0300 hours and 0600 hours therefore had an adoption time of at least 3-6 h, which was long compared to the median adoption time (see Results). Because of the highly skewed nature of the adoption time data, the error introduced by the inaccurate knowledge of the adoption times of these caterpillars is likely to be small.

We 'force adopted' any caterpillars that were not adopted within $48 \mathrm{~h}$ of being offered to the ants, by placing them directly in the ant nest chamber, and we noted the time of forced adoption (see below). Any caterpillars that died before adoption (which occurred only if they remained unadopted for nearly $48 \mathrm{~h}$ ) were replaced with fresh caterpillars, which were immediately force adopted. This was done so that each of the 106 colonies had four adopted caterpillars (see above).

\section{Statistical Analysis}

We carried out a one-way ANOVA on caterpillar mass, with site as the grouping factor, to test whether there was any difference in mass between caterpillars from the three sites. Since the adoption times of the four caterpillars in each nest were not independent (see Results), we used the median adoption time for each colony in all subsequent analyses.

Some caterpillars either were not adopted within $48 \mathrm{~h}$ of introduction, or died (presumably of starvation) before adoption. These caterpillars still yield valuable data on variation in attractiveness, however, since only caterpillars of very low attractiveness would suffer such fates. These caterpillars are analogous to those subjects in survival studies that either survive for the entire study period or whose fate is unknown, but that are observed as being alive at a known time (in our case caterpillars remained unadopted for the period of the study $(48 \mathrm{~h})$ or were known to be unadopted at a known time, the time at which they died). Since statistical techniques for dealing with such right-censored data are well developed (e.g. Kalbfleisch \& Prentice 1980), we analysed adoption times with these techniques, with unadopted or dead caterpillars being recorded as censored. Examination of the residuals of the median adoption times, and exploratory Kaplan-Meyer plots, revealed a log-normal distribution of the probability of being adopted over time, so that parametric survival analysis with a log-normal hazard function was most appropriate for the adoption time data.

Myrmica scabrinodis is not a host of M. alcon in the three sites where caterpillars were collected (T. D. Als \& D. R. Nash, unpublished data). Median adoption times for sets of four caterpillars adopted by $M$. scabrinodis subcolonies were therefore tested against those of sets of four caterpillars adopted by host species (i.e. data for adoptions by $M$. rubra and M. ruginodis subcolonies were pooled for this analysis). We used source site and ant species (M. scabrinodis versus others) as grouping factors in this analysis. 
Adoption times for M. rubra and M. ruginodis colonies were similarly treated as survival data with a log-normal hazard function distribution. We used a full three-way factorial design with caterpillar source site, ant source site and ant species as the grouping factor in this case. For statistical analyses we used Systat 7.0 for PC and JMP 3.2.2 for Macintosh.

\section{RESULTS}

Caterpillars emerged from the gentian plants collected at all three sites mostly around dawn and from midafternoon until midnight. There was a clear drop in emergence around midday and in the early hours of the morning. The mean mass $\pm \mathrm{SE}$ of fourth-instar caterpillars used for adoption was $1.79 \pm 26 \mathrm{mg}(N=430)$, and this did not differ significantly between the three sites (one-way ANOVA: $\left.\mathrm{F}_{2,427}=2.10, P=0.124\right)$.

Worker ants generally discovered the caterpillars within a minute of their introduction, so that differences in adoption time represent differences in the decision of colonies to adopt caterpillars rather than differences in discovery time. After being introduced to the foraging arena, the caterpillars typically remained relatively inactive, although some wandered slowly around the arena, but showed no obvious tendency to move in any particular direction. None of the caterpillars attempted to climb into the nest chamber by themselves, nor did they obviously avoid each other or stay clumped together. When encountered by a foraging Myrmica worker, caterpillars would typically become quiescent, usually withdrawing their heads under their anterior dorsal plates. We rarely observed the dorsal nectary organ producing fluid, which has sometimes been assumed to be necessary for adoption (e.g. in a series of videorecordings of larvae, only five out of 36 secreted droplets from the dorsal nectary organ before adoption; H. Kiesbüy, unpublished data).

Of the 430 caterpillars introduced to the Myrmica subcolonies, 24 (6\%) were adopted unobserved between 0300 and 0600 hours. All except three of these were introduced to the subcolonies before 2100 hours, and therefore had adoption times of more than $6 \mathrm{~h}$, while the remaining three were introduced at 2330 hours. Six caterpillars died before adoption (after a mean time of $37.4 \mathrm{~h}$, range 33.8-39.7 h), and a further 10 had not been adopted within $48 \mathrm{~h}$. All but one of these 16 unadopted or dead caterpillars originated from the BOTH site, showing a significant effect of caterpillar population on chance of remaining unadopted (exact test; Carr 1980: $P=0.038$ ), and all were presented to either $M$. ruginodis $(N=11$ caterpillars in three nests) or $M$. scabrinodis ( $N=11$ caterpillars in three nests) and none to M. rubra (exact test between ant species: $P=0.011$ ).

Observation of the adoption of caterpillars suggested that once the first caterpillar had been adopted, the others were often adopted in quick succession. If the probabilities of adoption of each of the four caterpillars by an ant colony were independent and did not vary over time, then adoption times are expected to follow an exponential distribution. We therefore compared the standard deviations in adoption times of the caterpillars
Table 1. The adoption time of Maculinea alcon caterpillars by Myrmica scabrinodis ants versus other species of Myrmica analysed as survival data with log-normal hazard function

\begin{tabular}{|lrrr|}
\hline Source & $d f$ & LR $\chi^{2}$ & $P$ \\
\hline Caterpillar source & & & \\
Ant species & 2 & 26.1 & $<0.001$ \\
Caterpillar source $\times$ Ant species & 1 & 33.5 & $<0.001$ \\
& 2 & 5.0 & 0.080 \\
\hline
\end{tabular}

The analysis is based on the median adoption time for each colony and includes as censored data those colonies where caterpillars were not adopted. Significance testing is based on likelihood ratio chi-square values.

introduced to each colony with those expected from an exponential distribution. Since a small sample from a population is expected to have a lower standard deviation than a large one, we obtained appropriate standard deviations for the exponential distribution by computer simulation, using the mean adoption time and appropriate sample size for each colony and 100 simulation runs. Only ant colonies with at least three caterpillars with accurately known adoption times were used in this analysis, all caterpillars that were force adopted or adopted between 0300 and 0600 hours being excluded. The observed standard deviation was lower than that expected in 83 out of the 94 colonies included in the analysis, showing that adoption times of caterpillars by the same colony were more similar than expected $\left(\chi_{1}^{2}=55.15, P<0.001\right)$ and cannot be regarded as independent. Thus it is likely that the adoption of the first caterpillar facilitates the adoption of other caterpillars by reducing the threshold for acceptance by that particular ant colony.

Figure 1 shows adoption times for all combinations of caterpillar type, site and ant species based on survival analysis of median adoption times for each ant colony. The two-way analysis of adoption by M. scabrinodis versus other colonies for the three sites showed a significant effect of caterpillar source and ant species (Table 1). Median adoption times for caterpillars adopted by M. scabrinodis were higher than those for caterpillars adopted by other ants for all three sites, and adoption of caterpillars from the BOTH site (Fig. 1b) took longer than adoption of caterpillars from the other two populations of M. alcon (Fig. 1a, c).

The three-way analysis of median adoption time of caterpillars for M. rubra versus M.ruginodis colonies showed a significant effect of all three factors, and a significant three-way interaction term (Table 2). Thus median adoption time differed between ant species, but the size and direction of the difference depended on where the ants (ant source) and the caterpillars (caterpillar source) were collected. Once again, there was a highly significant effect of caterpillar source site on the adoption time, with adoption of caterpillars from the BOTH site (mean adoption time $127.9 \mathrm{~min}, 95 \%$ confidence interval 75.35-217.2 min; Fig. 1b) taking an order of magnitude longer than adoption of caterpillars from the RUB (29.87 min, 95\% CI 24.03-37.15 min) and RUG sites (19.91 min, 95\% CI 11.79-33.62 min; Fig. 1a, c). 
Table 2. The adoption time of Maculinea alcon caterpillars by Myrmica rubra versus $M$. ruginodis ants analysed as survival data with log-normal hazard function

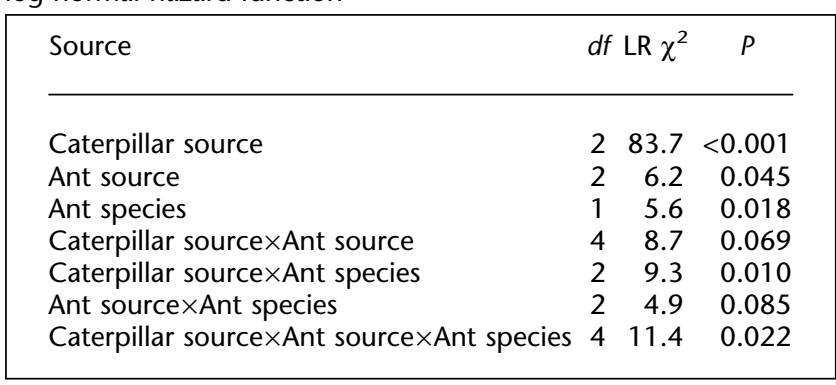

The analysis is based on the median adoption time for each colony and includes as censored data those colonies where caterpillars were not adopted. Significance testing is based on likelihood ratio chi-square values.

For the combinations of caterpillars and ants from the same site it might be expected, a priori, that differences in the observed adoption time would reflect differences in adaptation to the local host ants, with adoption occurring most quickly to colonies of the host species. This pattern is indeed evident in Fig. 1, where these combinations occur along the leading diagonal of the figure. Thus caterpillars from site RUG (Fig. 1a), which are normally found only in M.ruginodis nests, were adopted more quickly by $M$. ruginodis from site RUG than by M. rubra from site RUG (one-tailed $t$ test: $t_{8}=2.05, P=0.037$ ). Similarly, caterpillars from site RUB (Fig. 1c), which are normally found only in M. rubra nests, were adopted more quickly by $M$. rubra from site RUB than by M. ruginodis from site RUB (one-tailed $t$ test: $t_{8}=2.58, P=0.016$ ). Caterpillars from site BOTH (Fig. 1b), which are found in the nests of both host ants in the field, did not differ in their adoption times to M.ruginodis and M. rubra from site BOTH (two-tailed $t$ test: $t_{9}=1.14, P=0.283$ ).

For the combinations of caterpillars and ants from different sites, there was no clear pattern to the differences in adoption times. In five of these six combinations, adoption was faster to M. rubra than to $M$. ruginodis, probably being responsible for the overall significant effect of ant species in Table 2. However, caterpillars from a particular site were never consistently adopted faster by one ant species across all sites. The fastest adoption times for caterpillars from any site were to M. rubra nests from another site, suggesting some degree of local maladaptation.

\section{DISCUSSION}

Our results show that once a single caterpillar was adopted by a Myrmica colony, subsequent adoptions happened more quickly. The data for adoption times were described well by a survival model with a log-normal hazard function, showing that the probability of adoption increased rapidly after introduction of the caterpillars (probably because of the increasing chance that caterpillars had been discovered), reached a peak and then slowly declined. This suggests that caterpillar attractiveness decreases with time since emergence from the host plant, possibly because of depletion of energy reserves, desiccation and general decrease in health. Even though the majority of caterpillars were eventually adopted by each of the three Myrmica species tested, there were differences in the time taken for adoption in the laboratory. These differences cannot, on their own, account for differences in host specificity between the different sites. However, it is likely that adoption times would be even longer in the field, since the density of foraging ants will be much lower than in our laboratory colonies, resulting in additional discovery time. Our laboratory ant colonies also had an ideal substrate on which to discover and pick up the caterpillars and were not subject to adverse weather. This, in conjunction with the presence of predators and parasitoids in the field, means that the observed differences in adoption times are likely to represent real differences in survival probability in the field.

The differences in adoption time were most pronounced between $M$. scabrinodis, which is not used as a host in Denmark (T. D. Als \& D. R. Nash, unpublished data) and has correspondingly long adoption times, and M. rubra and M. ruginodis, which are Danish hosts. There were also differences in how fast the adoption occurred between M. rubra and M.ruginodis, but these differences depended on from where the caterpillars and the ant colonies were collected. Caterpillars from the BOTH site (Læsø Rønnerne) were less attractive to ant colonies of all three species from all three sites than caterpillars from the RUB and RUG sites (Vejers and Gyttegård). Caterpillars from these latter two sites, where one host species is used exclusively or predominantly, were adopted most quickly by that species when one considers only ants collected from that site. This suggests that there is local adaptation of M. alcon caterpillars to increase their attractiveness to the local major host species.

When adoption by ant colonies collected from distant sites is considered, the pattern of the host species having the shortest adoption time does not hold. Caterpillars from the RUB population were not consistently adopted faster by M. rubra colonies, and similarly caterpillars from the RUG populations were not consistently adopted faster by $M$. ruginodis colonies. If the adoption signals produced by the caterpillars are based on chemical mimicry of ant larvae (Akino et al. 1999), this suggests that there is considerable geographical variation in the surface chemistry of ant larvae. Recognition signals that have evolved in one area and in association with one host species may match the signals of an alternative host species more closely at a different site. The finding that the fastest adoption times for caterpillars from all three sites were to M. rubra colonies from different sites is intriguing, and is similar to findings of increased virulence for parasites transferred to distant populations (e.g. Kaltz et al. 1999; Thompson 1999). The adoption signals of M. alcon may have originally evolved for this species, and different components of the signals may have undergone selection in different directions in different geographical areas.

Together, these findings suggest that M. alcon and its Myrmica hosts are distributed in a coevolutionary mosaic 
(Thompson 1999) throughout Denmark. Initial selection pressure for specialization or generalization for each population of M. alcon may be driven by local host ant availability. Myrmica rubra is the most common Myrmica species at Vejers, and is the major host there, while $M$. ruginodis is the most common species, and the exclusive host, at Gyttegård (T. D. Als \& D. R. Nash, unpublished data). On Læsø where M. alcon uses both species as hosts, both M. rubra and M.ruginodis are relatively abundant within the range of gentians.

Of the 16 unaccepted caterpillars, 15 originated from the BOTH site. Caterpillars from this population also appeared to be less attractive in terms of adoption time than caterpillars from the two populations using a single host ant species, regardless of ant species and population. This is initially puzzling, since adoption times of the caterpillars from the other two sites were shorter, even to their nonhost species, so that this pattern is unlikely to arise from selection for the production of a less specific adoption signal. It seems rather that there has been selection for a less effective signal. The BOTH site differs from the other sites in a number of features, although it is not possible to determine which of these may be important without further comparative studies. Densities of ant nests within foraging range of gentian plants for all three species of Myrmica are very high on the BOTH site compared with the two sites with only one host ant species (D. R. Nash \& T. D. Als, unpublished data). The probability of being discovered by a Myrmica ant colony in a reasonable time is therefore likely to be much higher on the BOTH site, reducing the relative importance of a quick adoption once discovered. The BOTH site is also situated on the relatively small island of Læsø, with an area of some $100 \mathrm{~km}^{2}, 18 \mathrm{~km}$ from the mainland, and which has been above sea level for only about 3000 years (Andersen \& Sjørring 1997). This island is therefore likely to have a reduced species richness of predators and parasites (cf. Ahlen 1983; Clausen 1988), which may also decrease the relative importance of quick adoption. The apparently reduced attractiveness of caterpillars using two host ant species in any case suggests that there are considerable costs in the production of whatever signal (probably an ant larval pheromone mimic; Akino et al. 1999) is used to induce adoption, so that when selection on the need for quick adoption is relaxed, the strength of this signal is also reduced.

\section{Acknowledgments}

We thank Rebekka Gadeberg for advice, discussion and information on M. alcon sites and assistance in the adoption experiment, Jes Søe Pedersen, Graham Elmes, Jeremy Thomas and Judith Wardlaw for valuable suggestions and comments, Steffen Jørgensen (Randbøl statskovdistrikt), Dr Jur Beckmann and NordJyllands statskovdistrikt for permission to conduct fieldwork, Heine Kiesbüy for field assistance and Lone Hoy Jensen and Heine Kiesbüy for assistance in the laboratory. Two anonymous referees made useful comments on the manuscript.

\section{References}

Ahlen, I. 1983. The bat fauna of some isolated islands in Scandinavia. Oikos, 41, 352-358.

Akino, T., Knapp, J. J., Thomas, J. A. \& Elmes, G. W. 1999. Chemical mimicry and host specificity in the butterfly Maculinea rebeli, a social parasite of Myrmica ant colonies. Proceedings of the Royal Society of London, Series B, 266, 1419-1426.

Andersen, S. \& Sjørring, S. 1997. Geologisk set. Det nordlige Jylland. Brenderup, Denmark: Geografforlage.

Bagnères, A. G. \& Morgan, E. D. 1991. The postpharyngeal glands and the cuticle of Formicidae contain the same characteristic hydrocarbons. Experientia, 47, 106-111.

Bhatkar, A. \& Whitcomb, W. H. 1970. Artificial diet for rearing various species of ants. Florida Entomologist, 53, 229-232.

Carr, W. E. 1980. Fisher's exact test extended to more than two samples of equal size. Technometrics, 22, 269-270.

Clausen, I. H. S. 1988. Spiders (Araneae) from Nordmarken on the island of Læsø in Denmark: faunistic notes, habitat description, and comparison of sampling methods. Entomologiske Meddelelser, 55, 7-18.

Collingwood, C. A. 1979. The Formicidae (Hymenoptera) of Fennoscandia and Denmark: Fauna Entomologica Scandinavica. Vol. 8. Klampenborg: Scandinavian Science Press.

Elmes, G. W. 1991. The social biology of Myrmica ants. Actes des Colloques Insectes Sociaux, 7, 17-34.

Elmes, G. W. \& Keller, L. 1993. Distribution and ecology of queen number in ants of the genus Myrmica. In: Queen Number and Sociality in Insects (Ed. by L. Keller), pp. 294-307. Oxford: Oxford University Press.

Elmes, G. W., Thomas, J. A. \& Wardlaw, J. C. 1991a. Larvae of Maculinea rebeli, a large-blue butterfly, and their Myrmica host ants: wild adoption and behaviour in ant-nests. Journal of Zoology, 223, 447-460.

Elmes, G. W., Wardlaw, J. C. \& Thomas, J. A. 1991b. Larvae of Maculinea rebeli, a large-blue butterfly and their Myrmica host ants: patterns of caterpillar growth and survival. Journal of Zoology, 224, 79-92.

Elmes, G. W., Thomas, J. A., Hammarsted, O., Munguira, M. L., Martin, J. \& van der Made, J. 1994. Differences in host-ant specificity between Spanish, Dutch and Swedish populations of the endangered butterfly, Maculinea alcon (DENIS et SCHIFF.) (Lepidoptera). Memorabilia Zoologica, 48, 55-68.

Fiedler, K. 1991. Systematic, Evolutionary, and Ecological Implications of Myrmecophily within the Lycaenidae (Insecta: Lepidoptera: Papilionoidea). Bonn: Zoologisches Forschungsinstitut und Museum Alexander Koenig.

Fiedler, K. 1998. Lycaenid-ant interactions of the Maculinea type: tracing their historical roots in a comparative framework. Journal of Insect Conservation, 2, 3-14.

Fiedler, K., Hölldobler, B. \& Seufert, P. 1996. Butterflies and ants: the communicative domain. Experientia, 52, 14-24.

Figurny, E. \& Woyciechowski, M. 1998. Flowerhead selection for oviposition by females of the sympatric butterfly species Maculinea teleius and M. nausithous (Lepidoptera: Lycaenidae). Entomologia Generalis, 23, 215-222.

Figurny-Puchalska, E., Gadeberg, R. M. E. \& Boomsma, J. J. 2000. Comparison of the genetic population structure of the large blue butterflies Maculinea nausithous and M. teleius. Biodiversity and Conservation, 9, 419-432.

Gadeberg, R. M. E. \& Boomsma, J. J. 1997. Genetic population structure of the large blue butterfly Maculinea alcon in Denmark. Journal of Insect Conservation, 1, 99-111.

Kaaber, S. 1964. Studies on Maculinea alcon (Schiff.) rebeli (Hir.) (Lep. Lycaenidae) with reference to the taxonomy, distribution, 
and phylogeny of the group. Entomologiske Meddelelser, 32, 277-319.

Kalbfleisch, J. D. \& Prentice, R. L. 1980. The Statistical Analysis of Failure Time Data. New York: J. Wiley.

Kaltz, O., Gandon, S., Michalakis, Y. \& Shykoff, J. A. 1999. Local maladaptation in the anther-smut fungus Microbotryum violaceum to its host plant Silene latifolia: evidence from a cross-inoculation experiment. Evolution, 53, 395-407.

Kitching, R. L. \& Luke, B. 1985. The myrmecophilous organs of the larvae of some British Lycaenidae (Lepidoptera): a comparative study. Journal of Natural History, 19, 259-276.

Kutter, H. 1977. Hymenoptera, Formicidae: Fauna Insecta Helvetica. Vol. 6. Zurich: Schweizerische Entomologische Gesellschaft.

Liebig, W. H. 1989. Bemerkungen zur Biologie von Maculinea alcon SCHIFF. (Lep., Lycaenidae). Entomologische Nachrichten und Berichte, 31, 117-121.

Munguira, M. L. \& Martín, J. (Eds) 1999. Action Plan for Maculinea Butterflies in Europe. Convention on the Conservation of European Wildlife and Natural Habitats (Bern Convention), Nature and Environment, No. 97. Strasbourg: Council of Europe Publishing.

Pierce, N. E. 1987. The evolution and biogeography of associations between lycaenid butterflies and ants. In: Oxford Surveys in Evolutionary Biology (Ed. by P. H. Harvey \& L. Partridge), pp. 89-116. Oxford: Oxford University Press.

Pierce, N., Kitching, R. L., Buckley, R. C., Taylor, M. F. J. \& Benbow, K. F. 1987. The costs and benefits of cooperation between the Australian lycaenid butterfly, Jalmenus evagoras, and its attendant ants. Behavioral Ecology and Sociobiology, 21, 237248.

Schönrogge, K., Wardlaw, J. C., Thomas, J A. \& Elmes, G. W. 2000. Polymorphic growth rates in myrmecophilous inescts. Proceedings of the Royal Society of London, Series B, 267, 771-777.

Seppä, P. 1994. Sociogenetic organization of the ants Myrmica ruginodis and Myrmica lobicornis. Number, relatedness and longevity of reproducing individuals. Journal of Evolutionary Biology, 7, 71-95.
Seppä, P. 1996. Genetic relatedness and colony structure in polygynous Myrmica ants. Ethology, Ecology and Evolution, 8, 279-290.

Thomas, J. A. \& Elmes, G. W. 1989. The ecology and conservation of Maculinea butterflies and their ichneumon parasitoids. In: The Future of Butterflies in Europe 1989: Strategies for Survival (Ed. by T. Parlicek-van Beek, A. H. Ovaa \& J. G. Van der Made), pp. 116-123. Wageningen: Agricultural University Wageningen.

Thomas, J. A. \& Elmes, G. W. 1998. Higher productivity at the cost of increased host-specificity when Maculinea butterfly larvae exploit ant colonies through trophallaxis rather than by predation. Ecological Entomology, 23, 457-464.

Thomas, J. A. \& Wardlaw, J. C. 1992. The capacity of a Myrmica ant nest to support a predacious species of Maculinea butterfly. Oecologia, 91, 101-109.

Thomas, J. A., Elmes, G. W., Wardlaw, J. C. \& Woyciechowski, M. 1989. Host specificity among Maculinea butterflies in Myrmica ant nests. Oecologia, 79, 452-457.

Thomas, J. A., Clarke, R. T., Elmes, G. W. \& Hochberg, M. E. 1998a. Population dynamics in the genus Maculinea (Lepidoptera: Lycaenidae). In: Insect Populations (Ed. by J. P. Dempster \& I. F. G. McLean), pp. 261-290. London: Chapman \& Hall.

Thomas, J. A., Simcox, D. J., Wardlaw, J. C., Elmes, G. W., Hochberg, M. E. \& Clarke, R. T. 1998b. Effects of latitude, altitude and climate on the habitat and conservation of the endangered butterfly Maculina arion and its Myrmica ant hosts. Journal of Insect Conservation, 2, 39-46.

Thompson, J. N. 1999. Specific hypotheses on the geographic mosaic of coevolution. American Naturalist, 153, S1-S14.

Tolman, T. \& Lewington, R. 1997. Butterflies of Britain and Europe. London: HarperCollins.

Wardlaw, J. C., Elmes, G. W. \& Thomas, J. A. 1998. Techniques for studying Maculinea butterflies: II. Identification guide to Myrmica ants found on Maculinea sites in Europe. Journal of Insect Conservation, 2, 119-127.

Wynhoff, I. 1998. The recent distribution of the European Maculinea species. Journal of Insect Conservation, 2, 15-27. 